\title{
Does documenting the regulation process on a blog enhance pre-service teachers' self- and co-regulation in a collaborative project?
}

\author{
Moon-Heum Cho \\ Sungkyunkwan University, South Korea \\ Seongmi Lim \\ Ball State University, United States \\ Kyeonghwa Lee \\ Pukyong National University, South Korea
}

\begin{abstract}
Students often complain about unsatisfactory experiences resulting from disproportionate contributions to collaborative projects. To improve the experience, we applied regulation theory to design a process to document regulation on a blog and examined whether such documentation enhanced students' self-regulation and co-regulation skills while working on a collaborative project. The results indicate that students improved both their self- and coregulation skills significantly and they were highly satisfied with their experiences in the collaborative task. In addition, the content analysis performed on the documented regulation reveals that students engaged in diverse types of regulation processes through social interaction with group members. A discussion of teaching and learning strategies when using a blog in a collaborative task is included in this paper.
\end{abstract}

\section{Introduction}

Collaborating with group members is an essential skill that educators have deemed critical to student development in higher education (Summers \& Volet, 2010). Successful collaboration occurs through conscious self-regulation as well as co-regulation among group members (DiDonato, 2013; Panadero, Kirschner, Järvelä, Malmberg, \& Järvelä, 2015). Individually, students are expected to set goals and monitor and reflect upon their learning processes (Zimmerman, 2011). Collaboratively, group members are expected to share goals, divide roles and responsibly contribute to accomplishing common goals (Panadero \& Järvelä, 2015).

Often, however, group collaboration ends unhappily due to the lack of self-regulation, which causes freeloading, or co-regulation, which results from unsystematic group reflection (Summers \& Volet, 2010). Individual self-regulation and group co-regulation are, therefore, critical for the successful completion of a collaborative project (Hadwin, Järvelä, \& Miller, 2011; McCaslin, 2009; Volet, Vauras, \& Salonen, 2009).

Not every student can skilfully regulate in both modes in a collaborative project (Cho \& Lim, 2017; DiDonato, 2013; Panadero et al., 2015) perhaps because of a lack of experience in collaboration. According to social constructivist theory, students' lack of experience in regulation can be overcome by observing skilful peers' regulation processes (Volet, Summers, \& Thurman, 2009; Vygotsky, 1962). In addition, even if students know how to regulate, an absence of social support may discourage them from consistently engaging in high levels of regulation. Recognition and emotional support from group members are important for consistent regulation in collaborative projects (Cho \& Cho, 2013).

The use of social media is considered a promising method to support both self-regulation and co-regulation processes (Cho \& Lim, 2017; Halic, Lee, Paulus, \& Spence, 2010; Matzat \& Vrieling, 2016; McLoughlin \& Lee, 2010; Prestridge, 2014; Tan, Ladyshewsky, \& Gardner, 2010). By documenting regulation on social media on a regular basis, students can observe the various ways others regulate their learning and gain the opportunity to reflect upon their own regulation processes, learning and growing as more skillful learners (Cho \& Cho, 2013). In addition, by interacting with others on social media, students' regulation is recognised and supported by fellow group members. Although social media has considerable potential to be used as a tool to enhance students' self- and co-regulation, contributing to positive experiences in collaborative projects, very few empirical studies have been conducted on this subject (Al-Rahmi, Othman, \& Yusuf, 2015; Halic et al., 2010; Matzat \& Vrieling, 2016; Philip \& Nicholls, 2009). In this study, we 
explored the manner in which support via social media influences self-regulation and co-regulation in a collaborative learning task.

\section{Theoretical framework}

Social cognitive and social cultural theories of learning formed the framework for this study. From the social cognitive perspective, students develop self-regulation by observing the regulation processes of others, who in turn reinforce their self-regulation by providing feedback (Schoor, Narciss, \& Körndle, 2015). A blog provided the opportunity for students to do both (Philip \& Nicholls, 2009; Sullivan \& Longnecker, 2014); thus, their self-regulation was expected to improve through social interaction mediated by a blog. From the social cultural perspective, students' self-regulation is improved in social contexts through internalisation, often explained as a transition from more capable others' regulation to self-regulation (Hadwin et al., 2011; Hadwin, Wozney, \& Pontin, 2005; McCaslin, 2009). The transitional period is called co-regulation (Schoor et al., 2015), which can be influential not only to individuals but also to the motivation, cognition and emotion of groups (Järvenoja, Volet, \& Järvelä, 2013); therefore, we assumed that a blog, which provides a technology-mediated social context, plays an important role in co-regulation and contributes to the improvement of both self-regulation and co-regulation, leading students to successful experiences with group projects.

\section{Social media}

Social media, including blogs, Facebook, Twitter and wikis, have been proposed as tools to support selfregulation and co-regulation (Dabbagh \& Kitsantas, 2012; Matzat \& Vrieling, 2016; McLoughlin \& Lee, 2010; Tan et al., 2010). Dabbagh and Kitsantas (2012) suggested the potential of social media as a supporting tool for self-regulation in teaching and learning contexts as well as for co-regulation in collaborative projects. They also emphasised instructors' roles in employing social media in class, arguing that social media provides natural opportunities for students to practise self-regulation and co-regulation by allowing them to share information, provide and receive feedback from other students, synthesise information and evaluate and adjust their learning.

Reinterpreting Dabbagh and Kitsantas’ (2012) argument, Matzat and Vrieling (2016) empirically tested their hypothesis that teachers who provide plentiful self-regulated learning opportunities are more likely to integrate social media in their class if social media provides a natural opportunity for students to practise self-regulation. Based on the data collected from 459 Dutch secondary teachers, Matzat and Vrieling proved their hypothesis. In addition, they found a larger effect when they compared teachers who used more interactive social media, such as Facebook, Twitter, and WhatsApp along with YouTube, than those solely relying on YouTube. Their study is meaningful in that it shows the positive relationships between social media and teachers' efforts to use it as a tool to enhance students' self-regulation. More in-depth empirical research is necessary, however, to examine whether the use of social media enhances regulation skills and how students engage in the regulation process in social media.

In order to investigate the effects of social media on self-regulation, Cho and Cho (2013) trained students to engage in self-regulated learning. Students in the control group received no training. Cho and Cho (2013) found that college students trained in self-regulation used self-regulated learning strategies like planning and reflecting on Twitter more often than the untrained students in the control group. They demonstrated that social media with appropriate training provides opportunities for students to improve self-regulation; however, their study was conducted with an individual task. Very few empirical studies have been conducted with a collaborative project to examine how social media support students' self-regulation and co-regulation (Philip \& Nicholls, 2009; Sullivan \& Longnecker, 2014). In addition, Cho and Cho (2013) did not examine students' experience with social media, critical for further integration of technology in the classroom (Sullivan \& Longnecker, 2014). We therefore sought to determine whether social media are helpful in enhancing not only students' self- and co-regulation in collaboration but also experiences with regulation activities embedded in social media in a collaborative project.

\section{Self-regulation}

Well known to determine student achievement (Zimmerman, 2011), self-regulation has often been explained with multifaceted constructs like metacognition, motivation and the use of learning strategies 
(Pintrich, 2004; Zimmerman, 2011). Metacognitively, students set goals as well as monitor and evaluate their learning processes. Motivationally, self-regulated learners are intrinsically inclined to complete tasks, exhibit high self-efficacy and perceive high task value. In addition, self-regulated learners use deep-level learning strategies, such as elaboration, reorganisation and critical thinking. These constructs work reciprocally during the process of self-regulation (Pintrich, 2004; Zimmerman, 2011).

Researchers have found that self-regulation is not only significant in student achievement in individual tasks but also in positive learning experience in collaborative tasks (DiDonato, 2013; Panadero et al., 2015). For example, in a collaborative project, self-regulated learners not only use appropriate learning strategies but also monitor and support others' self-regulation processes (Cho \& Cho, 2013; Volet, Summers, et al., 2009). Panadero et al. (2015) found that college students with higher self-regulation levels are more likely to show higher co-regulation in a group. The results show the importance of self-regulation for group collaboration; however, researchers have consistently reported that not every student developed a high level of self-regulation (Zimmerman, 2011). Improving students' self-regulation should, therefore, be an important goal in the classroom (DiDonato, 2013).

One common instructional strategy educators use to promote students' self-regulation is high self-regulated learning tasks (DiDonato, 2013; McLoughlin \& Lee, 2010). These often involve a project-based collaborative learning context where an individual and other group members work together towards common goals. Loosely structured, the self-regulated learning task provides a problem space in which both individuals and the group interpret a problem and autonomy to choose a topic through discussion with other members. High self-regulated learning tasks require students to collaborate, support and help one another to successfully complete their projects.

Many social constructivists view the high self-regulated learning task as effective in enhancing students' self-regulation as well as co-regulation (DiDonato, 2013; Panadero \& Järvelä, 2015; Summers \& Volet, 2010). The task is interdependent with low and high regulators, providing multiple opportunities for regulation. For example, low-regulated learners observe high-regulated learners and learn how to self- and co-regulate. High regulators also acquire benefits through social recognition and further refinement of their inconsistent use of regulation strategies. DiDonato (2013) observed both low and high regulators' selfregulated learning at the beginning, middle and end of a nine-week middle school collaborative group project. She found that students' self- and co-regulation improved by the end and concluded that low and high regulators advanced their regulation skills by pursuing high self-regulated learning tasks in a classroom.

\section{Co-regulation}

Co-regulation, which involves interactions among more than two peers who coordinate self-regulation, is defined as "the temporary coordination of self-regulation among self and others" (Hadwin et al., 2011, p. 68). Through social interaction, regulatory work, including goal setting, monitoring and reflection, is distributed among group members. Co-regulation is negotiated through social interaction, assuming each participant brings a certain level of expertise in self-regulation to regulation contexts. Through social interaction and modelling, individual expertise in self-regulation transmits to others. For example, when Hadwin et al. (2005) analysed the patterns of teacher regulation and student regulation over time, they analysed one-on-one conversations between students and the teacher and found that teacher-directed regulation was relatively high at the beginning of the project, then decreased, paralleling a significant increase in student-directed regulation.

In collaborative work, each group member's participation is important in determining the form of regulation, denoted differently as socially shared regulation and other regulation (DiDonato, 2013; Hadwin et al., 2011; Panadero \& Järvelä, 2015; Volet, Vauras, et al., 2009). The most desirable and effective form of coregulation, socially shared regulation, occurs when each group member participates equally in the process of collaboration by engaging in regulation: suggesting and choosing topics, posing solutions, providing feedback and monitoring and reflecting upon the group process. Other regulation denotes a collaborative process in which one or more confident students take an instructive role in a group, dominating decisionmaking and leading regulation while other students simply follow, making it less desirable in collaborative work. 
Because collaborative tasks are more often used to enhance students' self- and co-regulation in both formal and informal learning contexts, Panadero and Järvelä (2015) called for more empirical research on coregulation, in particular on socially shared regulation. We have responded to their call with our examination of students' co-regulation in collaboration.

\section{Research questions}

The current study was designed to investigate whether documenting regulation on social media, specifically in a blog, enhances students' self-regulation and co-regulation in a collaborative project. In addition, we investigated detailed processes of co-regulation in collaboration along with student satisfaction. Our research questions follow:

(1) Does documenting the regulation process on a blog enhance students' self-regulation and coregulation skills?

(2) How does regulation occur in a collaborative project?

(3) To what extent are students satisfied with documentation activities and group collaboration?

\section{Method}

\section{Participants and ethics statement}

A total of 19 preservice teachers enrolled in a three-credit course called "Early Childhood Program Development and Evaluation" at a university in South Korea participated in the study. Most of the participants were female $(N=18)$, and their average age was $21.37(S D=1.07)$. The research was approved by the faculty members in the department where the research was conducted. Before participating in the pre and posttest surveys, students were informed that their participation was voluntary and that they could withdraw any time without penalty. Those who agreed to participate in the study submitted consent forms for research.

\section{Context}

The collaborative project took place over eight weeks during the semester and served as the final project, accounting for $50 \%$ of the total grade. The expected learning outcome for each group, comprising four or five students, was to collaboratively develop an educational program for young children on a topic of the group's choice.

During the period of collaboration, the instructor held weekly meetings with each group and provided any necessary assistance, including comments on the topic and content. Instructor scaffolding was more intensive at the beginning of the project, specifically when a group decided on the topic and scope of the program. Once the group decided on a topic and scope, the instructor provided minimal support necessary for the completion of the project. The members of each group were expected to be in control of their projects during the semester.

\section{Documenting the regulation process on a blog}

Naver, the Korean blog site used for this study, was chosen over other social media, such as Twitter or Facebook, for two reasons. First, students can write longer paragraphs on Naver; therefore, they could write about their regulation process without a word limit. Second, all the students already had an account on Naver and were familiar with the interface. Each group created a blog shared among group members. All students were expected to post one item of documentation about their regulation in the form of a learning journal entry and provide two responses to other group members' entries by each Monday.

\section{Instruments}

Four instruments were used to answer the research questions: self-regulation, co-regulation, weekly entries in learning journals and satisfaction. Detailed information about subscales appears in Table 1. Paper-based surveys were administered in the classroom by one of the researchers. All the students $(N=19)$ enrolled in the course participated in the both pre and posttest surveys. 
First, self-regulation consisted of three subscales - metacognition, motivation and learning strategies. Metacognition was measured with planning, monitoring and evaluation - adapted from the metacognitive awareness inventory (MAI; Schraw \& Dennison, 1994). Motivation was measured with intrinsic goal orientation, self-efficacy for learning and task value, adapted from the motivated strategies for learning questionnaire (MSLQ; Duncan \& McKeachie, 2005). Learning strategies were measured with critical thinking and peer learning, adapted from the MSLQ.

Second, co-regulation was measured with nine items, adapted from DiDonato (2013). They explain how an individual group member contributes to a collaborative project to accomplish common goals.

Table 1

Description of the instruments

\begin{tabular}{|c|c|c|c|c|c|}
\hline \multirow[t]{2}{*}{ Measure } & \multirow[t]{2}{*}{ Subscale } & \multirow[t]{2}{*}{ Sample question } & \multirow{2}{*}{$\begin{array}{l}\text { Number } \\
\text { of items }\end{array}$} & \multicolumn{2}{|c|}{ Cronbach's alpha } \\
\hline & & & & Pre & Post \\
\hline \multirow[t]{3}{*}{ Metacognition } & Planning & $\begin{array}{l}\text { I set specific goals before I } \\
\text { begin a project. }\end{array}$ & 7 & 0.81 & 0.85 \\
\hline & Monitoring & $\begin{array}{l}\text { I ask myself periodically } \\
\text { whether or not I am meeting my } \\
\text { goals for the project. }\end{array}$ & 7 & 0.81 & 0.84 \\
\hline & Evaluation & $\begin{array}{l}\text { I ask myself how well I } \\
\text { accomplished my goals once } \\
\text { I'm finished with a project. }\end{array}$ & 6 & 0.77 & 0.91 \\
\hline \multirow[t]{3}{*}{ Motivation } & $\begin{array}{l}\text { Intrinsic } \\
\text { motivation }\end{array}$ & $\begin{array}{l}\text { In a class like this, I prefer } \\
\text { course content that really } \\
\text { challenges me so I can learn } \\
\text { new things. }\end{array}$ & 4 & 0.81 & 0.84 \\
\hline & Self-efficacy & $\begin{array}{l}\text { I believe I will receive an } \\
\text { excellent grade in this class. }\end{array}$ & 8 & 0.91 & 0.92 \\
\hline & Task value & $\begin{array}{l}\text { I think I will be able to use what } \\
\text { I learn in this course in other } \\
\text { courses. }\end{array}$ & 6 & 0.85 & 0.94 \\
\hline \multirow[t]{2}{*}{$\begin{array}{l}\text { Learning } \\
\text { strategies }\end{array}$} & Critical thinking & $\begin{array}{l}\text { I often find myself questioning } \\
\text { what I hear or read in this } \\
\text { course to decide whether or not } \\
\text { I find it convincing. }\end{array}$ & 5 & 0.81 & 0.92 \\
\hline & Peer learning & $\begin{array}{l}\text { When studying for this course, I } \\
\text { often try to explain the material } \\
\text { to group members. }\end{array}$ & 3 & 0.69 & 0.86 \\
\hline Co-regulation & $\begin{array}{l}\text { Group } \\
\text { member's } \\
\text { regulation for } \\
\text { collaboration }\end{array}$ & $\begin{array}{l}\text { I double-check my work to } \\
\text { make sure I am doing it right for } \\
\text { a successful group project. }\end{array}$ & 9 & 0.90 & 0.92 \\
\hline \multirow[t]{2}{*}{ Evaluation } & $\begin{array}{l}\text { Evaluation of } \\
\text { collaboration }\end{array}$ & $\begin{array}{l}\text { Working with other students } \\
\text { produced quality work for this } \\
\text { project. }\end{array}$ & 3 & - & 0.92 \\
\hline & $\begin{array}{l}\text { Evaluation of } \\
\text { regulation on } \\
\text { blog }\end{array}$ & $\begin{array}{l}\text { I was able to develop new } \\
\text { regulation skills from other } \\
\text { members by reading about their } \\
\text { regulation processes on the } \\
\text { blog. }\end{array}$ & 4 & - & 0.87 \\
\hline
\end{tabular}

Note: Responses were recorded on a 7-point Likert scale, ranging from 1 (not at all true of me) to 7 (very true of me).

Third, each group member's weekly learning journal entries were kept on the group's blog. Because of the large number of messages on the blog, we randomly selected one group’s messages for our content analysis. 
We used results to explain how regulation occurred in a collaborative project. The group we chose included five members and generated 42 initial messages and 73 responses during the eight-week course.

Fourth, when considering satisfaction, we examined contentment with both collaboration and documentation on the blog as well as the answers to two open-ended questions. Satisfaction with collaboration was measured with three items adapted from Al-Rahmi and Othman (2013). Satisfaction with documentation on the blog was measured with four items adapted from Van Den Boom, Paas, and Van Merriënboer (2007). The two open-ended questions were:

(1) What did you like best when documenting the regulation process on the blog?

(2) If you could suggest one thing to improve the documenting process, what would you suggest?

A 7-point Likert scale, ranging from 1 (not at all true of me) to 7 (very true of me), was used on all scales.

\section{Procedures}

A two-hour orientation to the process of documenting regulation on a blog was provided, during which the instructor explained conscious contributions to a collaborative project in terms of both self- and coregulation. Each group created a blog on Naver, and both group members and the instructor joined it. Next, the instructor answered questions about regulation in a collaborative project. For the pre and posttest, selfregulation and co-regulation scales were administered. For the posttest only, a satisfaction survey was administered. Students' blog messages were collected for content analysis after the eight-week collaborative project was completed.

\section{Results}

\section{Improvement of self-regulation and co-regulation}

Paired sample $t$-tests conducted to examine students' improvement in self-regulation between the pre and posttests indicated significant improvement in all dimensions of self-regulation, such as metacognition, motivation and learning strategies (see Table 2).

Table 2

Students' self-regulation comparison between pre and posttest

\begin{tabular}{|c|c|c|c|c|c|c|c|}
\hline \multirow{2}{*}{$\begin{array}{l}\text { Self- } \\
\text { regulation }\end{array}$} & \multirow[t]{2}{*}{ Variables } & \multicolumn{2}{|c|}{ Pre } & \multicolumn{2}{|c|}{ Post } & \multirow[t]{2}{*}{$t$-statistics } & \multirow[t]{2}{*}{ Cohen's $d$} \\
\hline & & $M$ & $S D$ & $M$ & $S D$ & & \\
\hline \multirow[t]{3}{*}{ Metacognition } & Planning & 5.20 & 0.81 & 5.70 & 0.85 & $-2.20 *$ & 0.60 \\
\hline & Monitoring & 4.81 & 0.76 & 5.31 & 0.92 & $-2.26 *$ & 0.59 \\
\hline & Evaluation & 4.37 & 0.94 & 5.65 & 1.02 & $-5.85 * * *$ & 1.31 \\
\hline \multirow[t]{3}{*}{ Motivation } & Intrinsic motivation & 5.05 & 1.09 & 5.70 & 1.05 & $-2.58 *$ & 0.60 \\
\hline & Self-efficacy & 5.18 & 0.90 & 6.00 & 0.78 & $-4.70 * * *$ & 0.98 \\
\hline & Task value & 5.46 & 0.76 & 6.11 & 0.83 & $-2.95 * *$ & 0.82 \\
\hline Learning & Critical thinking & 5.39 & 0.99 & 5.76 & 1.14 & -1.31 & $\mathrm{n} / \mathrm{a}$ \\
\hline strategies & Peer learning & 5.81 & 0.88 & 6.26 & 0.88 & $-2.35 *$ & 0.52 \\
\hline
\end{tabular}

Note: All the variables were measured with a 7-point Likert scale, ranging from 1 (not true of me at all) to 7 (very true of me). Cohen's $d=(\mathrm{M} 2-\mathrm{M} 1) /\left[\left(\sigma_{1}{ }^{2}+\sigma_{2}{ }^{2}\right) / 2\right] * p<.05$, ** $p<.01$, *** $p<.001$

Specifically, for metacognition, planning significantly improved, $t(18)=-2.20, p<.05$ between Time 1 ( $M$ $=5.20, S D=0.81)$ and Time $2(M=5.70, S D=0.85)$; and Cohen's $d=0.60$, indicated a medium effect of documenting regulation on planning. Effect size means the magnitude of an intervention effect. Cohen's d is the difference between the means of the two groups divided by the average of their standard deviations. In general, an effect size of 0.2 or 0.3 is regarded as small; around 0.5 , medium; and 0.8 or more, large. Monitoring was significantly improved, $t(18)=-2.26, p<.05$ between Time $1(M=4.81, S D=0.76)$ and Time $2(M=5.31, S D=0.92)$, and Cohen's $d=0.59$. Evaluation was significantly improved, $t(18)=-5.85$, $p<.001$ between Time $1(M=4.37, S D=0.94)$ and Time $2(M=5.65, S D=1.02)$, and Cohen's $d=1.31$. 
With regard to motivation, we found significant improvement in three areas:

- intrinsic motivation: $t(18)=-2.58, p<.05$ between Time $1(M=5.05, S D=1.09)$ and Time $2(M$ $=5.70, S D=1.05)$, and Cohen's $d=0.60$

- $\quad$ self-efficacy: $t(18)=-4.70, p<.001$ between Time $1(M=5.18, S D=0.90)$ and Time $2(M=6.00$, $S D=0.78)$, and Cohen's $d=0.98$

- $\quad$ task value: $t(18)=-2.95, p<.01$ between Time $1(M=5.46, S D=0.76)$ and Time $2(M=6.11$, $S D=0.83)$, and Cohen's $d=0.82$.

With respect to learning strategies, critical thinking was not significantly different between Time 1 ( $M=$ 5.39, $S D=0.99)$ and Time $2(M=5.76, S D=1.14)$; however, peer learning was significantly improved, $t$ $(18)=-2.35, p<.05$ between Time $1(M=5.81, S D=0.88)$ and Time $2(M=6.26, S D=0.88)$, and Cohen's $d=0.52$.

Another paired sample $t$-test was conducted to examine students' improvement in co-regulation, $t$ (18) $=$ 4.81, $p<.001$ between Time $1(M=5.36, S D=0.72)$ and Time $2(M=6.16, S D=0.76)$, and Cohen's $d=$ 1.08 , indicating that documenting regulation on a blog improved students' co-regulation (see Table 3).

Table 3

Comparison of students' co-regulation as shown on pre and posttest

\begin{tabular}{|c|c|c|c|c|c|c|}
\hline \multirow[t]{2}{*}{ Variables } & \multicolumn{2}{|c|}{ Pre } & \multicolumn{2}{|c|}{ Post } & \multirow[t]{2}{*}{$t$-statistics } & \multirow[t]{2}{*}{ Cohen's $d$} \\
\hline & $M$ & $S D$ & $M$ & $S D$ & & \\
\hline Co-regulation & 5.36 & 0.72 & 6.16 & 0.76 & $-4.81 * * *$ & 1.08 \\
\hline
\end{tabular}

Note: Co-regulation was measured on a 7-point Likert scale, ranging from 1 (not true of me at all) to 7 (very true of me). Cohen's $d=(\mathrm{M} 2-\mathrm{M} 1) /\left[\left(\sigma_{1}{ }^{2}+{\sigma_{2}}^{2}\right) / 2\right] * * * p<.001$

\section{Regulation on a blog}

Content analysis was conducted with a total of 42 initial messages and 73 responses collected from a randomly chosen group. The first author of this study reviewed $20 \%$ of the messages, created a rough coding scheme based on those of Cho and Cho (2013) for regulation on Twitter, trained a graduate research assistant and performed the second blind coding with the research assistant. Because of the complexity of the regulation, coding schemes were revised and new ones were created. The unit of analysis was meaning. More specifically, if more than one regulation action was found in a sentence, the sentence was coded with more than one theme, and the sentences indicating only one regulation action were coded with one theme; therefore, 42 initial messages and 73 responses were coded with 278 themes (see Table 4). Initial agreement between coders for the entire analysis was 83\%. Discrepancies were resolved through discussion.

Table 4

Coding scheme

\begin{tabular}{|c|c|c|c|}
\hline Regulation & Definition & Example & Frequency \\
\hline \multicolumn{4}{|c|}{ Metacognitive control for group process } \\
\hline $\begin{array}{l}\text { Goal setting } \\
\text { and planning }\end{array}$ & $\begin{array}{l}\text { Indicating what a group has } \\
\text { decided to do or what a group } \\
\text { needs to do for their project }\end{array}$ & $\begin{array}{l}\text { We needed to establish overall } \\
\text { goals and subgoals before } \\
\text { developing our project on } \\
\text { traditional food. }\end{array}$ & 14 \\
\hline $\begin{array}{l}\text { Monitoring } \\
\text { project progress }\end{array}$ & $\begin{array}{l}\text { Overviewing what the group } \\
\text { did or how the project } \\
\text { developed }\end{array}$ & $\begin{array}{l}\text { We reviewed goals, objectives, } \\
\text { and activities for the project. }\end{array}$ & 9 \\
\hline $\begin{array}{l}\text { Reflecting } \\
\text { on group process }\end{array}$ & $\begin{array}{l}\text { Presenting thoughts and } \\
\text { reactions about whether or not } \\
\text { the group did well or what the } \\
\text { group could have done better }\end{array}$ & $\begin{array}{l}\text { I guess we had difficulty } \\
\text { choosing a topic because we } \\
\text { tried to create learning activities } \\
\text { even before we set clear goals } \\
\text { for the development of the } \\
\text { project. }\end{array}$ & 9 \\
\hline
\end{tabular}




$\begin{array}{ll}\text { Engaging } & \text { Participating in group } \\ \text { in collective } & \text { thinking } \\ \text { thinking } & \end{array}$

Suggesting ways of thinking (prompting others to think critically)
Raising ways to solve a problem or determining direction for the project.
We discussed various topics for the project. These topics included how to read a book, how to be healthy, and how to protect the environment.

If we focus on making bean paste, we may want to differentiate how our project differs from existing methods to make a soy paste mixed with red peppers.

\begin{tabular}{|c|c|}
\hline \multicolumn{2}{|c|}{ Interacting with group members on the group proj } \\
\hline $\begin{array}{l}\text { Providing feedback } \\
\text { on group members’ } \\
\text { ideas }\end{array}$ & $\begin{array}{l}\text { Offering reinforcement on } \\
\text { other members' ideas or } \\
\text { suggestions for the project }\end{array}$ \\
\hline Presenting & Offering own ideas \\
\hline $\begin{array}{l}\text { individuals’ ideas } \\
\text { to other } \\
\text { group members }\end{array}$ & to other group members \\
\hline $\begin{array}{l}\text { Recognising group } \\
\text { members' effort } \\
\text { in the project }\end{array}$ & $\begin{array}{l}\text { Showing awareness of others' } \\
\text { contributions to the project } \\
\text { (e.g., compliments) }\end{array}$ \\
\hline Sharing resources & $\begin{array}{l}\text { Making materials available to } \\
\text { others in the group; sharing } \\
\text { resources for a topic, } \\
\text { including lists of books, } \\
\text { websites, or You Tube videos }\end{array}$ \\
\hline $\begin{array}{l}\text { Supporting others' } \\
\text { ideas }\end{array}$ & $\begin{array}{l}\text { Reinforcing the ideas of other } \\
\text { group members }\end{array}$ \\
\hline
\end{tabular}

Interacting with group members on the group project

\begin{tabular}{|c|c|}
\hline \multicolumn{2}{|c|}{ Interacting with group members on external feedb } \\
\hline $\begin{array}{l}\text { Reflective thinking } \\
\text { after feedback }\end{array}$ & $\begin{array}{l}\text { Contemplating whether the } \\
\text { group is on the right track, } \\
\text { deciding what needs to be } \\
\text { done or how the group needs } \\
\text { to work }\end{array}$ \\
\hline $\begin{array}{l}\text { Receiving feedback } \\
\text { from others } \\
\text { on the group project }\end{array}$ & $\begin{array}{l}\text { Receiving feedback about } \\
\text { topic or content from the } \\
\text { instructor } \\
\text { or other group members }\end{array}$ \\
\hline $\begin{array}{l}\text { Revising } \\
\text { after feedback } \\
\text { from others } \\
\end{array}$ & $\begin{array}{l}\text { Making changes to the project } \\
\text { plans after hearing reactions } \\
\text { from the instructor }\end{array}$ \\
\hline \multicolumn{2}{|l|}{ Affect } \\
\hline $\begin{array}{l}\text { Encouraging group } \\
\text { effort }\end{array}$ & $\begin{array}{l}\text { Expressing positive thoughts } \\
\text { or attitudes to other group } \\
\text { members or the entire group } \\
\text { to motivate them to keep } \\
\text { working on the project }\end{array}$ \\
\hline Expectations & $\begin{array}{l}\text { Expressing positive thoughts } \\
\text { or attitudes about the } \\
\text { outcomes of the project. }\end{array}$ \\
\hline $\begin{array}{l}\text { Sympathy } \\
\text { for others }\end{array}$ & $\begin{array}{l}\text { Expressing positive feelings } \\
\text { to others while doing } \\
\text { the group project }\end{array}$ \\
\hline $\begin{array}{l}\text { Difficulties } \\
\text { of the task }\end{array}$ & $\begin{array}{l}\text { Sharing concerns about the } \\
\text { task while conducting the } \\
\text { project. }\end{array}$ \\
\hline
\end{tabular}

\section{Interacting with group members on external feedback} Reflective thinking Contemplating whether the

I hope we will make an
The topics of light, sound, and color will be appealing to children.

I was thinking about ways to make ice cream for children.

Your idea really helped us develop a program for children.

The following books explain how infant fecal matter indicates the health of a baby.

As you said, more feedback from others makes this project better. Reflecting on the professor's comments, our group focused on activities themselves instead of considering the goals for the project.

The professor suggested that we think in diverse ways about interesting topics that everyone can really work on.

After receiving the instructor's feedback, we embedded more explicit goals in the activities.

Let's create a good program that will help children. interesting and meaningful program.

I am sorry that we didn't choose the topic you suggested. I know you spent much time on it. Deciding the focus of the program among the group members was difficult. 
Positive feelings about project

Social greetings

Appreciation
Expressing attitudes such as excitement, happiness, and interest with regard to the project Offering short phrases of support to others Expressing gratitude to other group members for the group work
I know we will develop an excellent program for young children.

Well done.

I appreciate everyone's hard work.
16

An analysis of themes indicates that students engaged in diverse types of regulation (see Figure 1). Metacognitive control for the group process $(n=82)$ explained $29.50 \%$ of the regulations, demonstrating that the groups collaboratively steered the entire process of the project: setting goals, monitoring, reflecting, thinking collectively and suggesting ways of thinking.

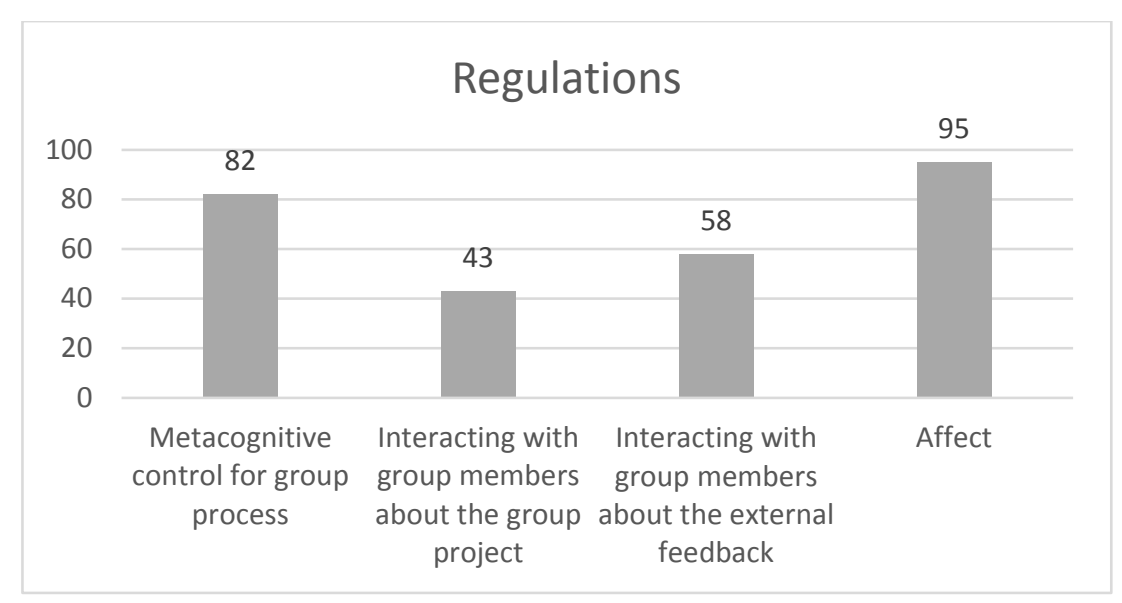

Figure 1. Number of regulations on the blog

Interacting with group members about the collaborative project $(n=43)$ explained $15.47 \%$ of the regulations. The results indicate that students very actively regulated their collaborative project when choosing a topic, generating ideas for program development, and deciding on evaluating methods.

Interacting with group members about external feedback $(n=58)$ mostly coming from the instructor explained $20.86 \%$ of the regulations. After students received external feedback from the instructor, they engaged in deep learning, represented with rethinking, revising, elaborating and organising content. Students seemed to take the instructor's feedback seriously and use it to improve project outcomes.

Finally, affect ( $n=95$ ) explained $34.80 \%$ of regulation processes related to social contexts. Diverse regulation activities occurred while students interacted with peers in social contexts. Students shared the difficulties of the tasks, and most of the messages were positive and encouraging, dealing with group effort. The results show that documenting the regulation process on social media, in this case on a blog in the form of weekly learning journal entries, supported students in regulating their learning process collaboratively and provided social support through interaction with other group members.

\section{Satisfaction}

The questions about the evaluation of the collaboration experience revealed that students were highly satisfied with the collaborative project $(M=6.49, S D=0.78)$ (see Table 5). Considering abundant collaboration studies reporting unsatisfactory experience with collaboration, we found the students' high satisfaction with the collaborative project in this study noteworthy. Because this was a small-scale study with no control group, we are unable to conclude that the positive evaluation of the collaborative project could be solely attributed to the results of the support for self- and co-regulation. Satisfaction with the 
collaborative project has nevertheless encouraged us to conduct a large-scale experimental research with a control group in the future.

Table 5

Student satisfaction with collaboration

\begin{tabular}{llcc}
\hline No. & Items & $M$ & $S D$ \\
\hline 1 & Working with other students enhanced my learning. & 6.26 & 0.87 \\
2 & Working with other students produced quality work for this project. & 6.63 & 0.83 \\
3 & By working with others, I was able to develop new knowledge that & 6.58 & 1.02 \\
& & \\
\hline
\end{tabular}

In addition, the subscale measuring satisfaction with documenting the regulation process on the blog indicated that in general students were satisfied $(M=6.05, S D=0.90)$ (see Table 6). Students reported that they developed new regulation skills and became more reflective by observing others. Students were relatively less satisfied, however, with the manner in which they posted about the regulating process on the blog and their interaction with others. Qualitative analysis of the open-ended questions explained student satisfaction with documenting the regulation process on the blog.

Table 6

Student experiences with support for regulation on social media

\begin{tabular}{llcc}
\hline No. & Items & $M$ & $S D$ \\
\hline 1 & $\begin{array}{l}\text { I was able to develop new regulation skills based on those of other } \\
\text { members by reading about their regulation processes on the blog. }\end{array}$ & 6.21 & 0.86 \\
& $\begin{array}{l}\text { Posting about regulation processes on the blog was a meaningful } \\
\text { way for me to reflect on my own learning. }\end{array}$ & 5.84 & 1.12 \\
3 & $\begin{array}{l}\text { Interacting with other students about regulation processes on the } \\
\text { blog helped me become a more effective learner. } \\
\text { Observing group members' regulation processes on the blog was a } \\
\text { good way to see myself as part of the group project. }\end{array}$ & 5.84 & 0.32 \\
\hline
\end{tabular}

Students provided several suggestions to improve their experience with documenting the regulation process on the blog. Some mentioned that they discussed their processes during face-to-face meetings outside the classroom, making doing so online redundant. Another student suggested that instead of documenting the regulation process by a designated day, every Monday in this case, some students wanted to be more flexible on the dates they posted journal entries. One stated:

Depending on group discussion and collaboration, project progress can be different. Some weeks, I had many things to share, but some weeks I didn't have much to reflect upon. I would suggest that the instructor allow students to choose the dates and number of journal entries they want to do.

In addition, several students mentioned that they wanted to see more responses to their journal entries, not only from their own group members but also from members of other groups and the instructor. One student stated, "I wanted to see more interaction in the comments on the blog so I can more actively provide and receive feedback."

Despite these suggestions for improvement, students provided very positive comments about documenting the regulation process on their blogs. Many students mentioned that they liked doing so in the form of weekly entries to a learning journal on the blog, and most students reported planning, monitoring and reflecting upon both individual contributions as well as the group's progress. One student said:

Through documenting the regulation process on our blog, I could monitor and reflect upon what I've done for the group project. I was able to see other group members' progress and their thinking process. Most of all, I could consciously overview our project's entire status and progress. 
Furthermore, students reported that by observing others' regulation process on the blog, they were able to understand and develop their ideas further. One student said, "Because I was able to see others' thoughts and ways of thinking, I could understand them as well as expand my ideas further."

Another student mentioned that interaction on the blog supported regulation, and yet another commented, "I liked documenting progress on the blog because it allowed me to interact with other group members. I enjoyed seeing their responses to my weekly journal entries, which kept me engaged in the journal activities." These comments demonstrate that social media contributed to providing opportunities for students to regulate and reinforce their consistent engagement in the regulation process for the collaborative project.

\section{Discussion}

The primary purpose of this study was to explore whether documenting the regulation process on a blog enhances students' self- and co-regulation, contributing to a positive experience with a collaborative project. The results indicate that students improved self-regulation and co-regulation skills significantly after documenting the regulation process regularly on a blog, which provided explicit opportunities for them to practise regulation and to observe others' regulation processes. In addition, many students were highly satisfied with the approach of documenting their regulation process on a blog.

We attribute the success of this intervention to three factors: effective use of a blog, appropriate structure of the learning task for collaboration and instructor feedback both inside and outside the classroom. First, the blog provided explicit opportunities for students to document their regulation process. By doing so and also by observing others' processes on a blog, they developed awareness not only of their own selfregulation but also the group's co-regulation status, which generated internal feedback for the progress (Butler \& Winne, 1995); furthermore, continuous awareness helped them develop their regulation skills (Pintrich, 2004; Zimmerman, 2011). In addition, by posting responses to others' initial messages and viewing others' support, such as affect (see Table 4), students provided and received social support and recognition from others, reinforcing their continued engagement in the regulation process during the collaborative project (Cho \& Cho, 2013). In the content analysis of the blog messages, we found that most of the affect messages were positive and included encouragement, high expectations about the project, sympathy, positive feelings about the project ending and appreciation of other members. The results suggest the importance of creating positive, supportive learning environments in which a blog facilitates the process (Halic et al., 2010).

Second, to promote self- and co-regulation, the instructor should assign manageable high self-regulated learning tasks, providing multiple opportunities for students to make collaborative decisions, interpret them in multiple ways and choose a topic through sharing and discussion (DiDonato, 2013). We used a collaborative learning task as a group project. Each group of students was expected to interpret the task, choose a topic and design and develop an educational program for kindergartners. While they pursued the project, they had to share ideas based on individual study, provide feedback to others, divide roles and complete the self-initiated or assigned work. Social media played a role in this collaborative learning process to document their content processing and report regulation.

Third, the instructor played a critical role in this course, present both inside and outside the classroom to support student groups. In class, the instructor taught skills necessary to complete the project and provided feedback on group work. Outside class, the instructor provided feedback and supportive messages on the blog. Researchers have agreed that instructors play a critical role in student collaboration (Al-Rahmi et al., 2015; Halic et al., 2010; Matzat \& Vrieling, 2016). Dabbagh and Kitsantas (2012) emphasised instructors’ use of social media to provide encouragement on self-regulation activities. Content analysis of blog messages demonstrate that instructors' feedback was influential to students' regulation process. Many students reported that they reflect upon and modify their plans, think about different approaches and revise the content thanks to the instructor feedback. Continued instructor presence seems to be significant in determining the success of the group project.

Our study contributes to the body of existing social media and self-regulation research in several ways. The way we integrated a blog into a collaborative project is an example for those who want to use a blog to enhance student regulation skills in class. We created the intentional activity of documenting the regulation 
process on social media, specifically a blog to support face-to-face collaboration. In addition to face-toface meetings for collaboration, students not only posted about their regulation process but also interacted with other group members on their blogs about their regulation process. Blog activities provided them with opportunities to reflect upon and understand others' thinking. Our study can be helpful for those who plan to integrate a blog to support collaborative learning in a face-to-face classroom.

In addition, our study contributes to regulation studies in which researchers have attempted to diversify methods to capture students' regulation processes. With the advancement of technology, more regulation researchers have called for alternative methods to capture the regulation process; for example, Schmitz, Klug, and Schmidt (2011) suggested web-based learning diaries. Our study is a response to their call for the study of a web-based diary, a blog in this case. Our study demonstrates that a vivid regulation process can be captured via social media.

Furthermore, the content analysis of the documentation process on a blog contributes to understanding recent developments in regulation theory via the social learning aspects of a collaborative project. The results of our content analysis provide snapshots of social regulation in such a project. Content analysis shows students shared their responsibility as learners and actively regulated not only their own learning but also their group learning, perhaps resulting in the improvement of both self- and co-regulation as well as high satisfaction with group work. Different from the focus of traditional research on individual students' regulation processes, contemporary regulation researchers are more interested in the way individuals and groups of students interact with one another in collaborative projects (DiDonato, 2013; Panadero \& Järvelä, 2015; Schoor et al., 2015). Although regulation researchers are interested in the social aspects of regulation, very little is known about the way regulation occurs among groups of learners. The content analysis is meaningful in that it shows specific examples of regulation in terms of the social aspects of a given situation, such as a collaborative project.

\section{Limitations}

Our study has several limitations. We adopted a pre-experimental design with a single group; therefore, the results of the study limit interpretation of the intervention effects on the improvement of students' self- and co-regulation. We had no control group because only one section of the course was offered once a year in the department in which we conducted the study. This is an issue that many educators encounter in classroom research. When considering the difficulties of improving self- and co-regulation in a general classroom context, however, we conclude that further research with both control and experimental groups in a large class setting would be beneficial. Comparing two groups' self- and co-regulation improvements will prove the actual effects of documenting the regulation process and provide external validity for the study. In addition, the small number of students $(n=19)$, predominantly females $(n=18)$, limits generalisability. The predominance of female students in the early childhood education course is hardly unusual; however, to generalise the results of the study, more gender-balanced samples are suggested for future researchers.

\section{Recommendations and conclusions}

In spite of these shortcomings, our research contributes to the literature of instructional support for enhancing regulation. Our study demonstrates that conscious integration of a blog to support collaborative learning contributed not only to promoting student regulation but also to satisfaction with collaboration. Content analysis of blog posts supports how both self- and co-regulation were significantly improved after the project was completed. Based on our results, we have two suggestions for instructors in higher education. for promoting students' active learning

First, instructors may give students autonomy in deciding frequency, deadlines and format of the interaction. In our study, the instructor decided the frequency, the deadlines as well as the rough format for the documentation; however, in our analysis of answers to open-ended questions, we found that students wanted to decide these on their own. Lee, Pate, and Cozart (2015) also suggested that providing students with choices and opportunities to personalise in their own context will help them engage in the learning process more seriously. 
Second, we suggest that instructors more actively participate in the regulation process on a blog. In our case, the instructor intensively participated in the blog for the first three weeks to scaffold student regulation; however, some students still wanted to see the instructor more actively participating on the blog by providing comments during the entire collaborative process. These students wanted recognition and support from the authority figure in the class. Two modes of active involvement are possible: One is to give direct comments on the blog so that the feedback can be shared with all students in the group or class. An instructor who is unable to provide feedback on all blog posts may give comments face-to-face in the classroom. Instructors may choose either mode, depending on their teaching contexts (e.g., teaching load). Either mode allows students to feel social support and recognition from the instructor, perhaps helping them to engage in more active regulation in collaborative projects.

Although many instructors view the potential of a blog as a tool to promote students' regulation skills or to facilitate collaborative work among students, not many of them integrate blogs to document student regulation and facilitate the learning process in collaborative projects (Philip \& Nicholls, 2009). We encourage instructors to integrate blogs to support students' regulation and learning and to engage them in more active participation than simply answering posted discussion questions or posting information. Instructors' active presence will enhance student engagement in the blog activity, which may result in the improvement of regulation skills, higher achievement, a sense of community and course satisfaction (Halic et al., 2010).

\section{References}

Al-Rahmi, W. M., \& Othman, M. S. (2013). Evaluating student's satisfaction of using social media through collaborative learning in higher education. International Journal of Advances in Engineering \& Technology, 6(4), 1541-1551. doi:10.7323/ijaet/v6_iss4

Al-Rahmi, W. M., Othman, M. S., \& Yusuf, L. M. (2015). The role of social media for collaborative learning to improve academic performance of students and researchers in Malaysian higher education. International Review of Research in Open and Distributed Learning, 16(4), 177-204. doi:10.19173/irrodl.v16i4.2326

Butler, D. L., \& Winne, P. H. (1995). Feedback and self-regulated learning: A theoretical synthesis. Review of Educational Research, 65, 245-281. doi:10.3102/00346543065003245

Cho, K., \& Cho, M.-H. (2013). Training of self-regulated learning skills on a social network system. Social Psychology of Education, 16(4), 617-634. doi:10.1007/s11218-013-9229-3

Cho, M.-H., \& Lim, S. (2017). Using regulation activities to improve undergraduate collaborative writing on wikis. Innovations in Education and Teaching International, 54(1), 53-61. doi:10.1080/14703297.2015.1117009

Dabbagh, N., \& Kitsantas, A. (2012). Personal learning environments, social media, and self-regulated learning: A natural formula for connecting formal and informal learning. Internet and Higher Education, 15, 3-8. doi:10.1016/j.iheduc.2011.06.002

DiDonato, N. (2013). Effective self- and co-regulation in collaborative learning groups: An analysis of how students regulate problem solving of authentic interdisciplinary tasks. Instructional Science, 41, 25-47. doi:10.1007/s11251-012-9206-9

Duncan, T. G., \& McKeachie, W. J. (2005). The making of the Motivated Strategies for Learning Questionnaire. Educational Psychologist, 40(2), 117-128. doi:10.1207/s15326985ep4002_6

Hadwin, A. F., Järvelä, S., \& Miller, M. (2011). Self-regulated, co-regulated, and socially_shared regulation of learning. In B. J. Zimmerman \& D. H. Schunk (Eds.), Handbook of self-regulation of learning and performance (pp. 65-84). New York, NY: Routledge.

Hadwin, A. F., Wozney, L., \& Pontin, O. (2005). Scaffolding the appropriation of self-regulatory activity: A socio-cultural analysis of changes in teacher-student discourse about a graduate research portfolio. Instructional Science, 33, 413-450. doi:10.1007/s11251-005-1274-7

Halic, O., Lee, D., Paulus, T., \& Spence, M. (2010). To blog or not to blog: Student perceptions of blog effectiveness for learning in a college-level course. Internet and Higher Education, 13, 206-213. doi:10.1016/j.iheduc.2010.04.001

Järvenoja, H., Volet, S., \& Järvelä, S. (2013). Research on motivation in collaborative learning: Moving beyond the cognitive-situative divide and combining individual and social processes. Educational Psychologist, 45, 15-27. doi:10.1080/00461520903433539

Lee, E., Pate, J., \& Cozart, D. (2015). Autonomy support for online students. TechTrends, 59(4), 54-61. doi:10.1007/s11528-015-0871-9 
Matzat, U., \& Vrieling, E. M. (2016). Self-regulated learning and social media - A 'natural alliance’? Evidence on students' self-regulation of learning, social media use, and student-teacher relationship. Learning, Media and Technology, 41(1), 73-99. doi:10.1080/17439884.2015.1064953

McCaslin, M. (2009). Co-regulation of student motivation and emergent identify. Educational Psychologist, 44(2), 137-146. doi:10.1080/00461520902832384

McLoughlin, C., \& Lee, M. J. W. (2010). Personalised and self regulated learning in the Web 2.0 era: International exemplars of innovative pedagogy using social software. Australasian Journal of Educational Technology, 26(1), 28-43. doi:10.14742/ajet.1100

Panadero, E., \& Järvelä, S. (2015). Socially shared regulation of learning: A review. European Psychologist, 20(3), 190-203. doi:0.1027/1016-9040/a000226

Panadero, E., Kirschner, P. A., Järvelä, S., Malmberg, J., \& Järvelä, H. (2015). How individual selfregulation affects group regulation and performance: A shared regulation intervention. Small Group Research, 46(4), 431-454. doi:10.1177/1046496415591219

Philip, R., \& Nicholls, J. (2009). Group blogs: Documenting collaborative drama processes. Australasian Journal of Educational Technology, 25(5), 683-699. doi:10.14742/ajet.1115

Pintrich, P. R. (2004). A conceptual framework for assessing motivation and self-regulated learning in college students. Educational Psychology Review, 16(4), 385-407. doi:10.1007/s10648-004-0006-X

Prestridge, S. (2014). A focus on students' use of Twitter - their interactions with each other, content and interface. Active Learning in Higher Education, 15(2), 101-115. doi:10.1177/1469787414527394

Schmitz, B., Klug, J., \& Schmidt, M. (2011). Assessing self-regulated learning using diary measures with university students. In B. J. Zimmerman \& D. H. Schunk (Eds.), Handbook of self-regulation of learning and performance (pp. 251-266). New York, NY: Routledge.

Schoor, C., Narciss, S., \& Körndle, H. (2015). Regulation during cooperative and collaborative learning: A theory-based review of terms and concepts. Educational Psychologist, 50(2), 97-119. doi:10.1080/00461520.2015.1038540

Schraw, G., \& Dennison, R. S. (1994). Assessing metacognitive awareness. Contemporary Educational Psychology, 19, 460-475. doi:10.1006/ceps.1994.1033

Sullivan, M., \& Longnecker, N. (2014). Class blogs as a teaching tool to promote writing and student interaction. Australasian Journal of Educational Technology, 30(4), 390-401. doi:10.14742/ajet.322

Summers, M., \& Volet, S. (2010). Group work does not necessarily equal collaborative learning: Evidence from observations and self-reports. European Journal of Psychology of Education, 25, 473492. doi:10.1007/s10212-010-0026-5

Tan, S. M., Ladyshewsky, R. K., \& Gardner, P. (2010). Using blogging to promote clinical reasoning and metacognition in undergraduate physiotherapy fieldwork programs. Australasian Journal of Educational Technology, 26(3), 355-368. doi:10.14742/ajet.1080

Van den Boom, G., Paas, F., \& Van Merriënboer, J. J. G. (2007). Effects of elicited reflections combined with tutor or peer feedback on self-regulated learning and learning outcomes. Learning and Instruction, 17, 532-548. doi:10.1016/j.learninstruc.2007.09.003

Volet, S., Vauras, M., \& Salonen, P. (2009). Self- and social regulation in learning contexts: An integrative perspective. Educational Psychologist, 44(4), 215-226. doi:10.1080/00461520903213584

Volet, S., Summers, M., \& Thurman, J. (2009). High-level co-regulation in collaborative learning: How does it emerge and how is it sustained? Learning and Instruction, 19, 128-143. doi:10.1016/j.learninstruc.2008.03.001

Vygotsky, L. S. (1962). Thought and language. Cambridge, MA: MIT Press.

Zimmerman, B. J. (2011). Motivational sources and outcomes of self-regulated learning and performance. In B. J. Zimmerman \& D. H. Schunk (Eds.), Handbook of self-regulation of learning and performance (pp. 49-64). New York, NY: Routledge.

Corresponding author: K. Lee, khlee@pknu.ac.kr

Australasian Journal of Educational Technology (C) 2017.

Please cite as: Cho, M.-H., Lim, S., \& Lee, K. (2017). Does documenting the regulation process on a blog enhance pre-service teachers' self- and co-regulation in a collaborative project? Australasian Journal of Educational Technology, 33(4), 166-179. https://doi.org/10.14742/ajet.2996 